\title{
Rio antirio bridge- an evaluation of the paragons involved in the decision making process
}

\author{
Karaoulanis \\ Andreas MBA MScEng
}

\begin{abstract}
In this paper, the author will try to evaluate all the paragons involved in the decision making process of one of the engineering wonders of the world, the Rio- Antirio cable bridge from the Greek state. The evaluation will be based on the decision making process presented by the Malmnas and Paulsson in their 2015 compendium at Stockholm University. The involved paragons that will be examined are the traffic, the geophysical concern, the economics of the project and the positive adjustments made by the Greek state in the formation of the contracts. The scope of this paper is to underline the complexity and the significance of the above mentioned project on a global range, as well as its importance not only to the local but to the whole European society.
\end{abstract}

Indexing terms/Key words: Reasoning; bridge; state; decision analysis; evaluation

Academic Discipline And Sub-Disciplines: Logic; Operations research

Type (Method/ approach): Literacy analysis; Research

\section{INTRODUCTION}

In this paper, the author will present the decision making process for the Rion- Antirrion bridge which is one of the most impressive bridges in the world and had vast impact in the local society of western Greece, not to mention its impact in the south Europe in terms of transportations.

The whole analysis will be based on the Malmnas and Paulsson compendium (2016) about decision support and in several other sources as well.

\section{THE PROJECT}

The Rion- Antirrion (RR) bridge is located in the Corinthian gulf, near the city of Patras, which is considers the capital of the Peloponnesus and provides a fixed link between Peloponnesus and the continental Greece over a stretch of water about 2,500 meters wide. The bridge is the biggest multi- span bridge in the world with continuous suspended deck of $2.252 \mathrm{klms}$.

It comprises of (ice.org.uk, 2015):

$\checkmark$ Four concrete piers, positioned on the seabed at a depth ranging from $48 \mathrm{~m}$ to $63.5 \mathrm{~m}$, reaching a height of $164 \mathrm{~m}$ about sea level

$\checkmark$ Two approach viaducts, one of pre-stressed reinforced concrete and one of steel composite construction

$\checkmark$ A total length of $3.5 \mathrm{~km}$

The project was completed on 2004, just some days prior to the Athen's Olympic Games opening ceremony.

The construction team encountered during the construction period a number of environmental challenges including:
$\checkmark$ Deep water
$\checkmark$ Deep soil strata of weak alluviums
$\checkmark$ Possibility of strong seismic activity and tectonic movements
$\checkmark$ High winds

In general, they had to overcome the $65 \mathrm{~m}$ depth of water, deep soil strata of weak alluviums, strong seismic activity in the region and tectonic movements. In order to overcome such issues, the construction company had to build, except the $2,252 \mathrm{~m}$ of multi span cable- stayed bridge, four pylons of 90 meters of diameter each on the seabed. In order to sustain such pylons, the top $20 \mathrm{~m}$ of soils were reinforced by means of metallic inclusions, based on an innovative concept.

The bridge was awarded a series of international awards, like the following:

$\checkmark$ Outstanding Structure Award 2006, of the International Association for Bridge and Structural Engineering (IABSE)

$\checkmark$ Award for Outstanding Concrete Structures 2006, of the International Federation for Structural Concrete (fib)

$\checkmark \quad$ Outstanding Civil Engineering Achievement Award 2005, of the American Society of Civil Engineers (ASCE) (for the first time awarded to a project outside the US) (Omega centre, n.d.). 


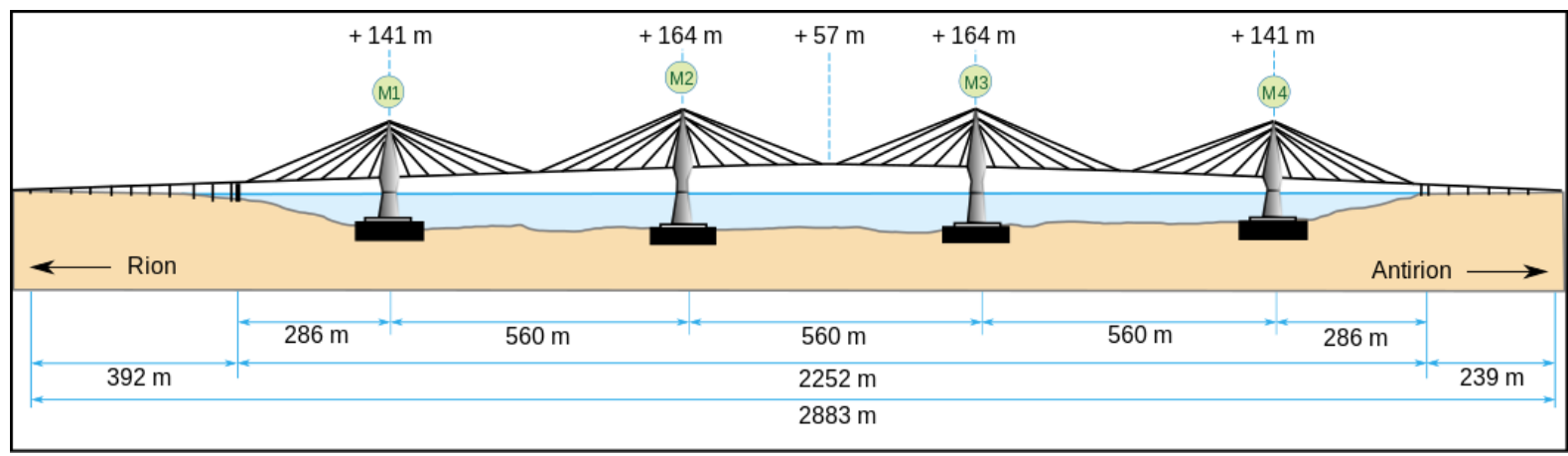

Figure 1: Diagram of the RionAntirionbridge (Wikipedia, n.d.)

\subsection{Shareholders}

The company which undertook the whole project is called Gefyra S.A. and was established in 1995 with sole aim to enter into the Concession Contract for the Rion- Antirrion Bridge with the Greek state and to implement it. As concessionaire, Gefyra S.A. had the responsibility for the design, construction, financing, maintenance and operation for the bridge during the 42- years concession period of time. In order such vast agreement to be fulfilled, the company has signed more than 50 agreements till today, including the construction contract with Construction Joint Venture and the numerous other detailed financing agreements with the Lenders of the project (Gefyra S.A., n.d.).

\begin{tabular}{|l|l|}
\hline $\begin{array}{l}\text { Shareholders of } \\
\text { Gefyra S.A. }\end{array}$ & $\%$ \\
\hline $\begin{array}{l}\text { VINCI } \\
\text { CONCESSIONS }\end{array}$ & $57.45 \%$ \\
\hline $\begin{array}{l}\text { AKTOR } \\
\text { CONCESSIONS }\end{array}$ & $22.02 \%$ \\
\hline J \& P AVAX & $12.14 \%$ \\
\hline ATHENA & $8.39 \%$ \\
\hline TOTAL & $100 \%$ \\
\hline
\end{tabular}

Table 1: Shareholders of Gefyra S.A. (Gefyra S.A., n.d.)

The total project cost was about $800,000,000$ Euros, including financial expenses incurred during the construction period. This financing came from the following sources:

\begin{tabular}{|l|l|}
\hline $\begin{array}{l}\text { FINANCING } \\
\text { SOURCES }\end{array}$ & $\%$ \\
\hline Share capital financial & $45 \%$ \\
\hline $\begin{array}{l}\text { State EIB } \\
\text { contribution }\end{array}$ & $45 \%$ \\
\hline $\begin{array}{l}\text { Loan from banks } \\
\text { guaranteed by a pool of } \\
\text { commercial bank } \\
\text { during the construction } \\
\text { period }\end{array}$ \\
\hline
\end{tabular}

Table 2: Financing Sources of the RR project (Gefyra S.A., n.d.)

EIB, was the sole lender of Gefyra S.A., providing the $45 \%$ of the long term finance of the project in question. The consortium of the guaranteeing commercial banks during the completion of the project, was:

\section{$\checkmark \quad$ Lead arrangers:}

Bank of Tokyo- Mitsubishi

Bank of America

\section{$\checkmark$ First tier participants:}

BayerischeLandesbankGirozentrale

Credit Agricole Indosuez 
SocieteGenerale

LandesbankGirozentrale

European Investment Fund

Commercial Bank of Greece

National Bank of Greece

$\checkmark$ Participants: Abbey National Treasury Services

Alpha Bank S.A.

Bank of Scotland

ING Bank

KBC Bank

Landesbank Hessen Thüringen

Lioydstsb Bank

Royal Bank of Scotland

CIC Banques

ETEBA

Bank of Ireland

De National Investeringbank

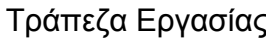

Depfa Group

Allied Irish Banks

NatexisBanquesPopulaires

Mizuho

Bank of Ireland

EFG Eurobank

NIB Capital Bank

(Sarantaki, 2007).

he construction Joint Venture is called KINOPRAXIA GEFYRA S.A., which is under the design and construction contract with Gefyra S.A. and a tripartite agreement with the Greek state and Gefyra S.A. The design period lasted from December 1997 till December 1999, while the construction period lasted from December 1999 till 15 August 2004, almost 5 months earlier than planned according to the concession contract

The construction companies that formed KINOPRAXIA GEFYRA S.A. and their shareholding are (Gefyra S.A., n.d.):

\begin{tabular}{|l|l|}
\hline VINCI Construction Grands Projects & $53 \%$ \\
\hline AKTOR ATE & $15.48 \%$ \\
\hline J \& P AVAX SA & $11.2 \%$ \\
\hline ATHENA SA & $7.74 \%$ \\
\hline PROODEYTIKI SA & $7.74 \%$ \\
\hline PANTECHNIKI SA & $4.84 \%$ \\
\hline
\end{tabular}

Table 3: KINOPRAXIA GEFYRA S.A. (Gefyra S.A., n.d.).

\section{THE GENERAL CONCEPT OF TIME FRAMING}

The project was designed in order to be operational just before the commencement of the Athens Olympic games of 2004 . As we stated in the paragraphs above, the project was concluded and delivered to the Greek state, some months before the concession plans, as described in the concession contract.

According to Peter O. (2011), an important paragon in decision making problems is time. This is very important in our case, as we can easily understand that: 


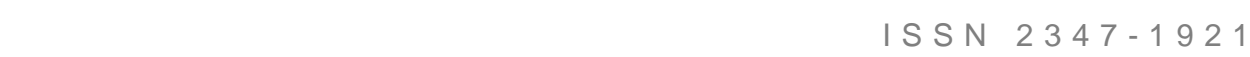

$\checkmark \quad$ As the Greek state decided that the time dead line was the inauguration of the Athens Olympic games, the time frame became very tight, especially for such difficult and huge construction.

$\checkmark \quad$ It is important to notice that in such decision making process, the time denominator is very important as every day that is passing by can make the decision process more stressful, due to the expenses and costs accumulation on a daily basis, something which can have vast impact in the correct final decision.

So, we can easily understand that the time element in our decision equation is a very strong component which needs to be taken under vast consideration.

As Drucker said "Making good decisions is a critical skill at every level". The question here is, when we come to decision making in state's level, the people responsible for the decision are only based on facts or also on emotional factors which spring from the potential time and maybe economic pressure due to the fact that they have to handle state money and sometimes because they are emotionally involved with the local society and the rest of the stake holders?

Giora K (1987), contacted an experiment involving 101 graduated students (59 women and 42 men), aged between 20 and 40 . They were requested to solve some decision problems using an interactive computer paradigm, while they were exposed to controllable, uncontrollable stress and no stress at all. The results indicated that those who were exposed to stress (controllable or uncontrollable), showed a significantly stronger tendency to offer solutions before all the available alternatives have been considered and to scan their alternatives in a non- systematic way than the other who weren't exposed to stress at all.

So, if we agree that managers who are responsible for decision making are just humans who are, logically enough, influenced by their environment, then the above mentioned example means that the decision making can be influenced by stress, something which can lead to wrong circumstances' evaluation thus wrong decision making. Of course, in our case, the decision making will be the responsibility of the Greek state, something which means that emotions should not be involved, but how and at which degree such thing is possible? The fact is that Greek citizens was expecting from their authorities to be able to decide under vast pressure and to have the ability to judge situations adequately and with transparency, especially when such large amounts of money are involved and such huge structures which will define in a great way the areas future are at stake.

According to Menger (1967), the company in question need to distinguish between two things:

$\checkmark \quad$ Evaluation of uncertainty

$\checkmark \quad$ The risk, the company is willing to take as a result of that evaluation

But how clear such an evaluation can be under time pressure? Also, we never need to forget that the decision making is not a company, but the Greek state, so there should be minimum risk and uncertainty involved must be evaluated very thoroughly before the decision making process.

Finally, in terms of time framing, we need to say that although the project was under a strict time dead line, the contractor managed to conclude the project months before the final dead line, just a few days before the commencement of the Athen's Olympic games, something which for such a difficult project and under such vast time pressure was considered to be a great achievement.

\section{THE DECISION MAKING PROCESS}

As Malmnas and Paulsson (2016) indicated, in decision making problems, an option in order to be considered need to be evaluated in accordance with its consequences.

Also, (Malmnas; Paulsson, 2016), as we have a finite number of options which have a finite number of consequences (tree nodes), we are likely to use the SSD approach of the decision theory.

In order to decide which the best possible path is, the Greek state needed to address some questions. According to Apostolakis (2004), in order to take the right decisions, the man in question has to face the following QRA questions:

1. What can possibly go wrong?

2. How likely is it to go wrong?

3. What are the consequences if something will go wrong?

According to Kochenderfer M.J.(2015), many important problems need to be answered via a decision making process, something which means that we need to choose between actions by basing our decision on imperfect observations while expecting unknown outcomes.

\subsection{The reasoning}

In this chapter, the author will stress the reasons the Greek state presented in order to decide the construction of this specific project.

According to the Greek Parliament (1996) legislative act about the RR bridge, the reasons why the Greek state decided to proceed with such a very important construction, are the following:

November $2016 \quad$ w w w. cirworld.com 
1. The connection between the Rion and the Antirion, is accomplished only by ferry boats, something which was creating vast problems in terms of transportation and accordingly in terms of trading between very important parts of the Greece, such as the Western Greece and the Peloponnese. It is indicative that the mean time for passing is about 45 minutes, while after the construction will be only 5-7 minutes, not to mention the safety of citizens and goods which will be increased dramatically. On annual basis from the RR narrows are passing by about two million vehicles and almost six million passengers.

2. It is additionally a very important construction for the whole Europe, and that's why it has been included and the Trans-European Transport Networks (TRANS EUROPEAN NETWORKS / TEN) as part of the highway Patras Athens - Thessaloniki -Efzonoi (PATHE). The decisions has been taken at the summits in Essen (December 1994) and Corfu.

The Rion-Antirion link road will connect some of the most important geographical regions of Greece, namely the Peloponnese with Western Central Greece and Epirus and it will contribute to the economic and cultural development of these

areas. The west road (Kalamataloannina to the Albanian border), will critically connect the Rion-Antirion link, to the two other road PATHE axis, which is the Egnatia road, which is also included in the Trans-European Networks and it will facilitate the communication of the country with Italy and other EU countries, including through the Patras and Igoumenitsa ports.

The main roads crossing RR are the following:
I. North- South axis road
II. Kalamata- Patras- loannina(Western road)
III. Patras- Athens- Thessaloniki-Evzonoi (Eastern road- PATHE).
IV. Eat- West axis road
V. Antirion- Lamia road.

3. The Rion - Antirion link will bring direct benefits to users, including:

I. Reduction of transit time by an average of 40 minutes per car, which entails the reduction of the total travel cost for both passengers and goods transportation

II. Significant improvement of the quality and comfort of transit

III. Significant improvement of transit reliability

IV. Ensuring the transit regardless the weather conditions

V. Strengthening the competitiveness of existing businesses and creating conditions for establishing new in so far geographically remote areas of northwestern Greece

VI. Promote socio-economic development of that region

4. The RR link will create conditions for residential development, productive reconstruction of the area and this is why the Ministry of Environment promoted the following:

* The implementation of the study of the spatial impact of community programs and policies in the whole region of Western Greece

* Development and implementation of the Special Spatial Study of the Corinthian Gulf.

* The development of Spatial Studies in the prefectures of Achaia and Etoloakarnania.

* The completion of the special regulatory study for this area and the Rio community study

* The protection, enhancement and restoration of castles Rio - Antirio as preserved Byzantine Monuments.

* This integrated spatial, urban and environmental planning out the land use conditions and building restrictions on residential development and compatible productive initiatives that will contribute to sustainable development of the region.

It is very important one to notice that the execution and completion of the $5^{\text {th }} \mathrm{RR}$ project is of great importance as it will:

Stop the traffic disruption and the burdens of the area, with the separation of urban from long distance traffic

$\checkmark \quad$ Reduce pollution from traffic, since vehicles will not be stuck in the ports but will continue to their destinations without delay.

$\checkmark \quad$ It will free the RR district from high voltage pylons $(\Delta . E . H)$.

$\checkmark \quad$ It will convert the RR region in a modern residential area.

$\checkmark \quad$ It will provide improved ferry facilities in order ferries to provide their services to users who still prefer it from the RR bridge. 
$\checkmark \quad$ It will take special care in order to highlight the Byzantine castle of the region.

5. The Project of the linkage, both during the construction stage and at the stage of its operation, will create thousands of jobs that would give way and open new horizons for the employment of the RR region. More specifically:

$\checkmark \quad$ It will recruit manpower from the RR region, who accordingly will be trained in order to be used in the construction of the bridge

$\checkmark$ An increase in the job vacancies in the between 400-1,000 placements depending on the construction phases.

$\checkmark$ Significantly increase in job vacancies in order to meet the needs of the construction phase in a great number of operations in the area which are involved in the construction as providers of raw material, machinery etc.

6. The Greek Ministry of Environment under the second Community Support Framework has included many other interventions in terms of infrastructure and transportation in the Western Greece in parallel ways to the RR bridge construction. In the following table we can see these interventions analytically with their respective budgets:

\begin{tabular}{|l|l|}
\hline Agrinio and Arta detour with a total length of $48 \mathrm{klm}$ & 23 billion drachmas \\
\hline Preveza- Aktio linkage & 14 billion drachmas \\
\hline Part of Paraionia road & 4 billion drachmas \\
\hline Parts of the Antirion- loannina road & 2 billion drachmas \\
\hline Coastal road Igoumenitsa- Preveza & 1.9 billion drachmas \\
\hline Igoumenitsa harbour (as Egnatia road gate) & 15 billion drachmas \\
\hline Patras harbour & 13 billion drachmas \\
\hline Katakolon harbour & 1 billion drachmas \\
\hline Killini harbour & 1 billion drachmas \\
\hline Preveza harbour & 1 billion drachmas \\
\hline Araxos airport & 2.2 billion drachmas \\
\hline
\end{tabular}

Table 4: Parallel to the RR bridge construction interventions in the Western Greece (Greek Parliament, 1996).

Note that the depth of the sea, the high seismicity of the area and the difficult foundation conditions, will make the project internationally unique and highly original. For the design and construction the most modern methods and techniques will be applied, which will be further refined, i.e. remote preparation of foundation soil with robots, consolidation and strengthening of soil punching vertical metal tubes the application of construction methods in open sea as the oil platforms in the North Sea etc.

${ }^{1}$ The drachma was the Greece's local currency by 1996 when this construction was decided by the Greek government. When Greece became an equal member of the Eurozone and adopted Euro as its currency the equivalent of 1 euro was 340.75 drachmas, so i.e. 23 billion drachmas can be converted to an equal of about 67,498,165 Euros. 


\subsubsection{Economic information about the project}

The needs and capital sources during the study period - Construction Project (with entry into the case of the 1.7.1996 Convention) are as follows:

I. Requirements

\begin{tabular}{|l|l|}
\hline $\begin{array}{l}\text { Guaranteed manufacturing costs in accordance with } \\
\text { its tender contractor (prices 1.7.1993) }\end{array}$ & 449 million ECU ${ }^{2}$ \\
\hline $\begin{array}{l}\text { Update (from 1.7.1993 until the completion of } \\
\text { construction) }\end{array}$ & 112 million ECU \\
\hline Construction period interest and financing costs & 104 million ECU \\
\hline $\begin{array}{l}\text { AU operating costs until the start of the project, } \\
\text { including the fees of the independent Research and } \\
\text { Control Office Supervisor }\end{array}$ & 26 million ECU \\
\hline TOTAL & 691 million ECU \\
\hline
\end{tabular}

Table 5: Requirement costs (Greek Parliament, 1996).

II. Sources of financing

\begin{tabular}{|l|l|}
\hline Share capital & 65 million ECU \\
\hline Financial contribution of Public & 306 million ECU \\
\hline Loan (EIB) & 320 million ECU \\
\hline TOTAL & 691 million ECU \\
\hline
\end{tabular}

Table 6: Sources of Financing (Greek Parliament)

III. Comments on the financing of the project:

$\checkmark \quad$ The financial contribution of the Greek government will amount to $200 \mathrm{MECU}^{3}$ at 1.7.1993 prices, will be adjusted in accordance with the terms of the Tender Documents, based on the interest rate ECU bond curve. The total amount of the above financial contribution, which is estimated at current prices (to the Convention enters into force on 1.7.1996 case) to $306 \mathrm{MECU}$, which will be the maximum amount of the financial contribution of the government for the project, expected to come:

a. The amount of $150 \mathrm{MECU}$ from existing commitment of the European Regional Development Fund (ERDF) through the Operational Program "Accesses and Road Axes' of the 1994-1999 Community Support Framework.

b. The amount of about $50 \mathrm{MECU}$ which has already been approved as a loan from the European Coal and Steel Community (E.C.S.C.) to the Greek State. The amount of the loan corresponds to the estimated value of Community origin of steel to be used for the construction of the Project and

c. The remaining $56 \mathrm{MECU}$, from the program of public investments over the seven year period of study and construction of the Project.

2 "The European Currency Unit ( $\mathrm{E}$ or ECU,) was a basket of the currencies of the European Community member states, used as the unit of account of the European Community before being replaced by the euro on the 1st of January 1999, at parity. The ECU itself replaced the European Unit of Account, also at parity, on the 13th of March 1979. The European Exchange Rate Mechanism attempted to minimize fluctuations between member state currencies and the ECU. The ECU was also used in some international financial transactions, where its advantage was that securities denominated in ECUs provided investors with the opportunity for foreign diversification without reliance on the currency of a single country" (Wikipedia,n.d.)

${ }^{3} \mathrm{MECU}:$ million ECU 


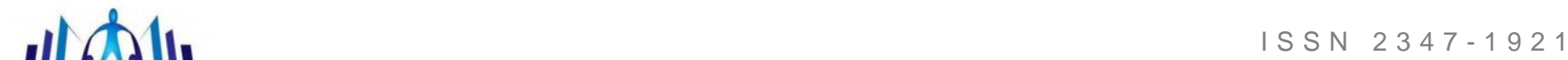

d. The contractor's contribution (46.5 MECU at prices 1.7.1993) will be adjusted annually by the rate ECU bond curve, like the Financial Contribution of the developer (Greek state), and is estimated to amount to 65 MECU (with entry into the case of the 1.7.1996 Convention).

e. The loan of $320 \mathrm{MECU}$ is estimated to be granted by the European Investment Bank (EIB) and is expected to last for 25 years. The first 8 years of borrowing is expected to be paid only interest.

\subsubsection{Positive adjustments in favour of the Greek state}

During the negotiation, there were several positive adjustment in favour of the Greek state, in terms of sustainability of the project and quality assurance, such as:

$>$ There is the possibility that the concession agreement can be limited in duration provided a specific clause on compulsory shortening of the concession period and delivery of the project to the Greek state, when the contractor will reach the predetermined height value of his invested capital (ROE). This Return On Equity (ROE), was set at $11.5 \%$ in real ECU prices, while according to the contractor's tender, the concession period was set in 42 years, which is 7 years of construction plus 35 years of operation. Note here that according to the estimates of the financial director of the project, the above mentioned ROE, may be achieved after 18 to 23 years of the project's operation.

$>$ The Greek state compiled a special tripartite agreement between the Greek state, the contractor and the construction consortium (and all its members), which states that all members have to fulfil all the obligations contained in the study and construction of the project, which have undertaken by the contractor. The Greek state is completely safe by this agreement as the construction consortium is completely responsible for the risk in constructing the RR bridge.

$>$ The Greek state, eestablished a dual level control mechanism and supervision of the project by the Greek Government and by special independent Audit Firms. Such measure will ensure to the greatest possible extent that the design and construction of this very difficult technical project will be in accordance to the specifications given and within the allotted time.

$>$ A number of Commercial banks, led by the BANK OF AMERICA, guarantee the contractor's loans during the critical - due to the nature and the technical difficulties of the project - seven-year study and construction period of the project.

$>$ The initial acceptance of the concession agreement by the commercial banks involved heavily in the project is a guarantee for the on time finance of the project.

$>$ Due to the long period of time for the loans repayment, the commercial banks led by BANK OF AMERICA, are not bound to provide guarantees that for the project's loans. Therefore, became necessary that the Greek state will be able to provide to the contractor a loan in order to help him repay the project's loans which will be under the commercial laws provided. It is clear that such an option will be activated only if and when and to the extent that would be required if the project revenues are not sufficient to repay the loan and in combination to the guarantees which can be provided by the European Investment Fund (EIF)

\subsubsection{The chronicle of the project's commencement}

The decision for starting such a difficult and time consuming construction was not an easy task and the road from the conceiving of the idea till the implementation of the project passed thru several milestones which are presented in the following paragraphs:

Over the past 15 years the Greek state attempted two more times to start the specific project with no success. This project is one of the most difficult ever due to the combination of deep sea, seismicity of the area and unfavorable soil characteristics.

$\checkmark \quad$ In 1980 started the first international invitation to tender, which however did not go beyond the first phase concerning expressions of interest and general recommendations because the construction Enterprises did not demonstrate serious interest.

$\checkmark$ During the period of 1986 to 1987 a series of studies was performed in order to investigate the conditions of the project area in order to launch the second tender process.

$\checkmark \quad$ In 1987, the Greek state opened the second international competition for the design - construction and financing of the project (ie borrowing and parallel offsets offer). Five (5) Consortia / Groups expressed their interest at this stage. Two of them were blocked before the opening of financial bids, due to an apparent violation of the contest rules. Also, the offers of the other consortia identified technical problems of considerable size. This second contest was cancelled on December 1990.

$\checkmark \quad$ The Ministry of Environment, Physical Planning and Public Works began in 1991 the competition procedure, the third in a row, with a supply system which included the design, construction, self-financing and operation of the Project accompanied with a Concession Contract. The Convention for ratification is the result of this competition.

This new competition was conducted on the basis of feasibility studies, environmental studies and Tender Documents (TD) who drafted the Collaborating Agencies "Eupalinos TAE" AND "RENDEL PALMER \& TRITTON". In particular in the 


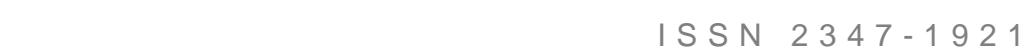

drafting of the Tender Documents involved and Financial Consultants "KOURI CAPITAL" AND "KIDDER PEABODY" (Greek Parliament, 1996).

The above mentioned construction offices took into account the results of the following investigations:

$\checkmark \quad$ From the "GEOCEAN" and the Laboratory "GEOTECHNIKI" for geotechnical investigations.

$\checkmark \quad$ From the School of Engineering of the University of Patras and the National Technical University of Athens on the sea currents, the wind speed calculations and seismic- tectonic activity of the Project area.

During the contest, seven consortiums expressed their interest Groups, while only six were preselected. Two withdraw and while the Greek state expected offers from the four left, finally, only two proceeded to the offerings stage, namely the RIO-ANTIRIO consortium and the Group GEFYRA. The RIO-ANTIRRIO offer was excluded due to substantive and procedural issues. So evaluated and negotiated only the GEFYRA's GROUP offer.

The GEFYRA Group's offer Proclaimed as the Promoter of the Project, assessed by the established Committees, as fixed in the TD, namely the Tender Committee, the Special Tender Evaluation Committee and Commission Recommendation for Award. All these committees were supported in their work by the Office Directors and by other consultants on specific issues.

During the negotiations it sought and obtained the configuration of the Concession Agreement and the Tripartite Agreement and their Appendices, in a way that their content:

$\checkmark$ Responding to the substance of TD,

$\checkmark$ To serve the smooth, according to specifications, and specific time implementation in such a difficult and complex technical project,

$\checkmark$ Correspond to the international practice for financing similar projects.

\section{EVALUATION OF THE REASONING/ARGUMENTS PRESENTED BY THE GREEK STATE}

In this chapter, the author will try to evaluate the decision taken by the Greek state on the basis of the reasoning presented in the previous chapter.

\subsection{Paragons involved in the decision making process}

According to Lincoln et al. (2011), there are four components involved in the ethical decision making process:

$\checkmark$ Moral sensitivity (moral awareness): is an individual's ability to understand that a situation involves a moral issue (Rest, 1994, cited in Lincoln et al.2011)

$\checkmark \quad$ Moral judgment: That refers to how we formulate and evaluate which possible solution to the moral issue has moral justification

$\checkmark$ Moral motivation (moral intention): Refers to the intention to choose the moral decision over another solution representing a different value. "For example, an individual may recognize two solutions to a dilemma, one that results in an increase of personal power and one that is morally right. In this instance, moral motivation is the individual's intention to choose the value of morality over the value of power" (Lincoln et al., 2011, p.57).

$\checkmark$ Moral courage (moral action): Is the individual's action in the situation and involves courage, determination and the ability to follow through with the moral decision

According to Menger (1967), there are two important paragons which we need to consider during the decision making process, the strength of our motive and the probability of achieving our aim

The author concludes that two paragons are the most important in decision making, the strength of our motive and the probability of achieving our aim. The second element is different than the first, unless we can explicitly include uncertainty in the idea of motivation.

In this specific project several paragons involved, such as the ethical one as the decision needed to be clear and straightforward, the traffic background of the area, the geophysical characteristics of the area, the socio- cultural profile of the region and the economical paragon.

\subsection{Traffic Reasoning evaluation}

In terms of traffic, it is more than obvious that the Greek state was right that the project will relief the whole are of Western Greece and Peloponnese in terms of transportation. It was not only that before the construction, the Western GreecePatras connection was only some ferry boats, but it is also the fact that simultaneously with the project a numerous other sub- projects were running, i.e. Agrinio and Arta detour with a total length of $48 \mathrm{~km}$, etc. as we can see in table 4 .

Western Greece is a very problematic area in terms of transportation and such a bridge was a vast advancement not only for the area but also for the Europe too as it became a vivid part of the Patras- Athens- Thessaloniki- Efzonoi PATHE road which crosses the whole Greece's mainland and connects Greece with the Balkan countries and the rest of the Europe.

November $2016 \quad$ w w w. cirworld.com 


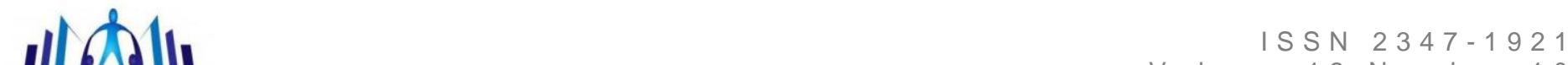

Several issues like the winter weather problems incurred often and made the passage from Rio to Antirio and vise- versa via the ferry boats restricted many times, were terminated. On the other hand, some argumentation about why the bridge did not combined a rail way platform are very justified because mainly the whole western Greece suffers from the lack of a railway web and the same goes for the Peleponnese. So, it is the author's prevalent opinion that such a huge construction with such a big budget could have undertaken the implementation of the rail way platform in combination with the implementation and future expansion of the rail way web of the Western Greece, something which could have created an impeccable traffic web in the area.

Another important remark here is that the author would expected that the specific project as the biggest in Greece the last decades and one of the biggest in the world, should have been the cornerstone of a bigger project regarding the traffic web of the whole Greece's mainland. If that project was implemented in combination with other sub- projects, i.e. the reconstruction of the Patras- Athens road which even today is one the worst roads in Greece, the results would have been tremendous and the impact of the project to the general good of the people in the country would have been enormous. On the contrary, the project, in the way it was implemented affected mainly the regional population.

In general, the author believes that the Greek state's argumentation about why such a project would have been implemented was right and convincing, regarding the needs of the specific area. Some objections could be that the Greek state should have a more wide perspective of the situation in terms of the general traffic conditions in Greece and how this project could have been part of a bigger one on national scale, as well as in terms of the railway platform and the greater rail way presence in the area combined with the above mentioned platform.

\subsection{Risk evaluation in terms of geophysical concerns}

According to Dr.Carolyn Pararas-Carayannis (2007), "The Gulf of Corinth in Greece is one of the most seismic regions in Europe and contains one of the fastest opening, geological rift zones in the world. The rate of north-south expansion near the project site is estimated to be about $1.6 \mathrm{~cm}$ per year and the tilting and uplifting of its southern shore, locally in some areas, has been estimated to be at a rate of approximately $1 \mathrm{~mm}$ per year (Cordis Project, 2005; Bell, McNeill \&Henstock, 2006, cited in Paparas-Carayannis, 2007).

We can easily understand from the above, that the project had a big impediment to overcome, which was the big seismic activity of the area. Such impediments are very important when it comes to bridge's construction and has been a severe paragon in the past in terms of bridge's stability.

If we add to the above that the construction is the longest cable-stayed, fully suspended bridge in the world. It was inevitable that when the Greek state took the responsibility to implement such an aspiring project, was fully aware of the risks involved in such construction, not only due to the seismic factor, but also due to other problems in the specific project area, such as the big depth of the sea in the specific area where the pylons were constructed etc.

The engineers involved in the project had to overcome many additional unique engineering problems like the risk of tsunamis due to potential future seismic activity in the region, the absence of bedrock and stiff seabed soil at the depth of 60-65 meters, the high velocity wind drifts which could cause damage to the bridge, and the ability to provide large clearance below the deck in order to provide enough space for big commercial ships to cross the narrows (PaparasCarayiannis, 2007).

From what was described in the reasoning part from the Greek state, it is quite obvious that the Greek state was aware from the very beginning of the challenges of such a demanding project. The Greek government took all the safety reasons that needed to be taken in order to facilitate the construction and provide the safety needed.

Although the project was risky enough as a unique one on this planet, the Greek state implemented all the necessary evaluation and research needed in the preliminary stages of the project in order to be sure that the project can be implemented.

So, it is the author's idea that in terms of justifying the Greek state's decision making in terms of whether the project was safe and the construction wasn't of high risk, the verdict is that the reasoning was convincing. As we have the luxury to watch the construction 12 years after its completion, we can say that till today almost nothing happened in terms of safety, something which is a very strong argument in terms of whether the project was based on the right safety measures and specifications.

\subsection{Economic evaluation}

In terms of project's financing, the Greek state's argumentation was really convincing. The whole project was going to be safely implemented in terms of financing as the main financers with $90 \%$ of the whole project's financing were the Greek state and the EIB and the whole financing plan was supported/ guaranteed by a big group of banks with BANK OF AMERICA to be the leading one in this group. So, in terms of financial risk of the project's execution we had no problem at all and the Greek state was very justified in its decision.

Some argumentation can be that the total cost was high enough for a country like Greece and not only that but the timing of the project's execution was not the best one, considering that the plan was the project to be completed just days before the inauguration of the Athen's Olympic games of 2004. This means that the Greek state at this momentum had a very heavy financial load to carry and the connection of the Olympic project which involved a lot of construction and road subprojects to such a big financially project could bee very stressful on the short and on the long run too.

November $2016 \quad$ ww w. cirworld.com 


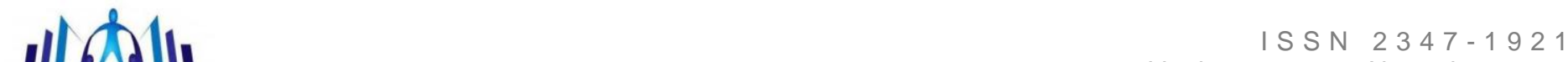

Another argument against the Greek state's decision could be that the tolls to be paid by the passing by people are quite expensive. Nowadays they are at the price of 15 euros for a private use vehicle, for only one direction, so someone who want to go to Patras from Messologi and return back will have to pay 30 euros, while the price for the ferries is only 5 euros per person while the kids don't have to pay a ticket. This created the phenomenon that despite the paramount bridge and all its benefits, a large number of locals, and not only, still prefer the ferries from the bridge.

It was very important and very well justified that the whole area will be profited from the job vacancies that will be created due to the construction process.

Also, in the Parliament act, there is no detailed financial- technical study/ argumentation based on numbers about the argumentation that the consortium company which undertook the project will reach its financial goal of $11.5 \%$ ROE in 8 to 12 years by manipulating the toll profits. So, the author tends to believe that such an approach is a bit abstract and cannot be a guarantee basis upon which a financial decision can be based.

Finally, the Greek state mentions that consortium RIO ANTIRIO's offer was was excluded due to substantive and procedural issues. It seems that a more detailed reasoning of this decision should have been presented by the Greek state in order to create a clarity in terms of the whole process of the contest, something which is very important in terms of decision making of the state. In general the author cannot say that the moral obligations of the Greek state were not followed during the decision and execution of the project. The clarification needed in some points was just in order to justify more profoundly something that we are sure about, that the project didn't involve any unethical paragon.

\subsection{Positive adjustments evaluation}

In terms of all the positive adjustments made by the Greek state in all the agreements signed by all parties, the Greek state presented strong arguments and facts which in general can create the safe environment needed when we have to deal with money of tax paying citizens and the clarity needed in such occasions.

It is very important that the contractor has a ceiling of $11.5 \%$ in terms of reaching his target ROE, something which means in plain words that the Greek state will be benefited on the long run if the contractor will reach his target quickly. The only obscure point here is the presentation that the contractor will reach his target in 8-12 years of operation of the project as mentioned in the previous sub- chapter, something which was presented in the Greek parliament as a strong argument although wasn't justified properly.

Also, the part of the tripartite agreement which clearly states that the contractor is fully responsible for the risk involved in the RR bridge construction is very good and secures the Greek state in great deal in terms of any risks that will emerge during the construction period.

The dual control mechanism for the audit of the project is a very good mechanism which will secure the whole project execution in a great extent.

An argument against the so called positive adjustments is that as mentioned in previous chapters, the Greek state will be able under the commercial laws to provide to the contractor a loan in order to help him with the project loans as the long period of re- payment of the loans (42 years)has as a result that the big commercial banks involved cannot guarantee for the full re- payment of the project's loans. It is the author's argument that such loan has to be defined more precisely in terms of interest etc. and has to be explained to the Greek parliament if it has any kind of risk, because if the contractor will not be able to pay the project's loans maybe is under a difficult economic situation and a new loan will maybe make the situation worst, something which has a lot of risks involved for the Greek state in terms of the full re- repayment of the second loan which will be with the money of Greek citizens.

\subsection{General evaluation}

In general, the Greek state's argumentation of why this project is important and of why this project has secure financial and construction terms is well placed. It is the author's prevalent idea that this project was a necessity for the area and that the decision making process was very well accomplished by the Greek state.

Some obscured points in the whole argumentation were presented in the previous chapters but the general picture is that the whole process was well accomplished.

Something that didn't mention anywhere in this project description the government presented in the Greek parliament was if the several stakeholders were asked about their opinions. It is very important that the stakeholders, which except the Greek state and the contractor, are the local citizens and all the professional involved, have to be asked about their opinion of the project in terms of how this project will affect their lives and their children lives on the short and long run.

When it comes to the general good, the possibility of some stakeholders to lose something in terms of revenues etc. is not that important as the needs of the many outweigh the needs of the few, but the government need to have a grip on the local society in general. Also, we need to underline that the Greek state protected the moral obligations that surged from such decision against its own voters.

\section{CONCLUSIONS}

In this paper, the author presented the description and the decision making process of one of the most important infrastructure projects of the modern Greece, the Rio- Antirio bridge, which had a tremendous impact in the whole region of Western Greece and Peloponnese.

November $2016 \quad$ w w w. cirworld.com 


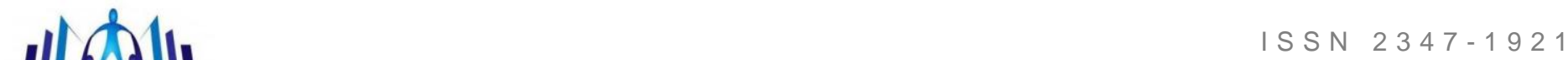

The author presented that Greek state's argumentation and tried to evaluate such argumentation under the prism of financial, traffic, social and general issues involved in the decision making process.

In general the whole argumentation was rather convincing, although some obscured points were underlined by the author. The moral obligations of the government were under criticism but in general the project seems to have such moral obligations under strong consideration.

\section{REFERENCES}

[1] Apostolakis E. George, 2004. "How useful is quantitative risk assessment?".Risk Analysis, Vol.24 (3), pp. 515-520.

[2] Greek Parliament, 1996. "Ratification of the Concession Agreement and the Tripartite Agreement Project Study, Construction of BRIDGE Finance and Operations RIO - Antirio, determination of environmental conditions and regulation related issues" [online]. Available at:<www.hellenicparliament.gr/UserFiles/2f026f42.../NOM_SYM_EE_2395_HГ17.doc> [Accessed 03 October 2016]

[3] Ice.org.uk., 2015. "Design and construction of Rion- Antirion "HarilaosTrikoupisbridge"”. [online]. Available at: <https://www.ice.org.uk/disciplines-and-resources/case-studies/design-and-construction-of-rion-antirion-bridge> [Accessed 02 October 2016].

[4] Gefyra S.A., n.d. Home page [online]. Available at: <http://www.gefyra.gr/en/company/GEFYRA-AE/> [Accessed 02 October 2016].

[5] Giora K., 1987. "Decision making under stress: Scanning of alternatives under controllable and uncontrollable threats". Journal of Personality and Social Psychology, Vol 52(3), pp. 639-644.

[6] Lincoln S.; Holmes A., 2011. "Ethical Decision Making: A Process Influenced by Moral Intensity" Journal of Healthcare, Science and the Humanities. Vol 1 (1), 2011.

[7] MalmnasPer Erik and Paulsson Andreas, 2016. Decision problems and ways of handling them [pdf]. Version 07.08 .2016 Available <https://ilearn2.dsv.su.se/pluginfile.php/88134/mod_resource/content/6/MalmnasPaulsson2016.pdf. [Accessed 29 August 2016]

[8] Menger, K., 1967. The Role of Uncertainty in Economics. In M. Shubik, ed. 1967. Essays in Mathematical Economics, in Honor of Oskar Morgenstern. Princeton, N.J.: Princeton University Press

[9] Omega centre, n.d. "Project profile. Greece RionAntirionbrgidge" [pdf]. Available at: <http://www.omegacentre.bartlett.ucl.ac.uk/wp-content/uploads/2014/12/GREECE_RIONANTIRION_PROFILE.pdf> [Accessed 02 October 2016].

[10] Paparas- Carayannis, 2007. "THE RION-ANTIRION BRIDGE An Engineering MarvelSpanning the Gulf of Corinth, Greece". Drgeorgepc.com. Available at: <http://www.drgeorgepc.com/ArtRionAntirionBridge.html> [Accessed 04 October 2016].

[11] Peters O., 2011. "The time resolution of the St Petersburg paradox" The royal society publishing. Org [online]. Available at: <http://rsta.royalsocietypublishing.org/content/369/1956/4913> [Accessed 18 September 2016].

[12] Sarantaki, 2007. "The European and the Greek experience of PPP: The case of the Rion- Antirion Bridge", Master Thesis, Department of Economic and Regional Development, Pantion University, Athens.

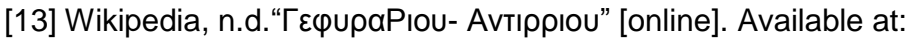

<https://el.wikipedia.org/wiki/\%CE\%93\%CE\%AD\%CF\%86\%CF\%85\%CF\%81\%CE\%B1_\%CE\%A1\%CE\%AF\%CE\%BF\%C F\%85-\%CE\%91\%CE\%BD\%CF\%84\%CE\%B9\%CF\%81\%CF\%81\%CE\%AF\%CE\%BF\%CF\%85> [Accessed 02 October 2016].

[14] Wikipedia, n.d. "European Currency Unit". [online]. Available at: <https://en.wikipedia.org/wiki/European_Currency_Unit> [Accessed 03 October 2016].

\section{Author Biography}

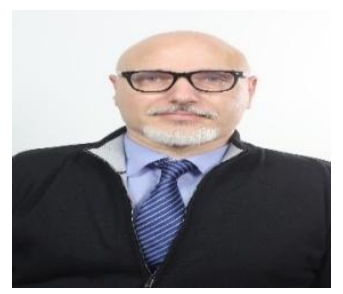

Andreas Karaoulanis, MBA, MsEngholds a MBA degree with distinction in Industrial Management and Economics form Blekinge Institute of TechnologySweden and a MSc in Engineering with honorsfrom Aristotle University of Thessaloniki .He is currentlyenrolling on a MSc in decision support and risk analysis in Stockholm University Sweden. He is

very experienced after 25 years of working in several industries like engineering, banking, retail and consulting. He is an ESL teacher and a Linked In blogger with many managerial posts. 